\title{
SPORTSKI MARKETING U HRVATSKOM NOGOMETNOM KLUBU RIJEKA ${ }^{4}$
}

\begin{abstract}
SAŽETAK
Popularizacijom natjecateljskog sporta postignuto je da su neki sportovi postali visoko rangirani na ljestvici interesa u društvu. Među njima posebno mjesto zauzima nogomet. Razlog takve popularnosti je financijske prirode. Poznato je da se ulažu ogromna financijska sredstva u klubove i njihove igrače koji na tržǐ̌tu postižu visoku cijenu. Nesumnjivo je da marketing ima veliku ulogu u tom području. lako se u suštini ne razlikuje od marketinga proizvodnih poduzeća, sportski marketing ipak ima neke specifičnosti koje se ogledaju kroz pojedine elemente marketing miksa. Tako promatrajući, sportski proizvod ima veći raspon mogućnosti zadovoljenja potreba samih korisnika. U radu je predstavljen HNK Rijeka, čiji zavidni rezultati u sportskom smislu, bez dodatnih ulaganja u marketing, nisu dovoljan preduvjet i za ostvarivanje pozitivnih poslovnih rezultata. Poslovni rezultati se očekuju efikasnim ulaganjem financijskih sredstava i kvalitetno odabranom marketinškom strategijom. Premda postoje brojni oblici financiranja kluba, jedan od ciljeva HNK-a Rijeka jest i da se samofinanciranje kluba podigne na višu razinu. Iz tog su razloga marketinške aktivnosti kluba usmjerene i na oblik promocije koji rezultira povećanjem financijskih resursa kroz svoje obožavatelje, navijače i publiku u širem smislu.
\end{abstract}

Ključne riječi: sportski marketing, sportski proizvod, promocija, HNK Rijeka

\section{UVOD}

Uspješni poslovni subjekti ostvaruju svoje ciljeve prodajom svojih proizvoda ili usluga. Pri tome se drže definicije marketinga koja ih usmjerava prema aktivnostima identificiranja, predviđanja i zadovoljenja potreba potrošača kroz proces stvaranja i razmjene, što u konačnici rezultira stvaranjem profita (Grbac, 2007). Uloga marketinga poznata je svakom tržišno usmjerenom subjektu bez obzira na područje poslovanja. No svako područje ima i svoje specifičnosti koje zajedno s dodirnim točkama naglašavaju poseban pristup poslovanju. Jedno od takvih područja je i sport. U radu je prikazan marketing u sportu na primjeru HNK-a Rijeka s elementima marketing miksa i njihovom kombinacijom radi postizanja poslovnih rezultata spomenutog kluba.

Poznatiji pod nazivom „sportski marketing", marketing u sportu nastao je pojavom vrhunskog natjecateljskog sporta, kada je sport postao poduzetnički i ekonomski zanimljiv. Sport može utjecati na gospodarstvo u smislu povećane potrošnje i proizvodnje ili kao element turističke

\footnotetext{
Mr. sc., predavač, Veleučilište u Rijeci, Vukovarska 58, 51000 Rijeka, Hrvatska. E-mail: robert.strahinja@veleri.hr Univ. spec. oec., asistent, Veleučilište u Rijeci, Vukovarska 58, 51000 Rijeka, Hrvatska.E-mail: mgolob1@veleri.hr Studentica, Veleučilište u Rijeci, Vukovarska 58, 51000 Rijeka, Hrvatska.E-mail: tsubasic@veleri.hr Datum primitka rada: 15. 1. 2017.; datum prihvaćanja rada: 15. 3. 2017.
} 
ponude (Hodak, Botunac, 2006:138). Natjecateljski sport u pravilu egzistira na većim financijskim ulaganjima gdje se i očekuje povrat takvih ulaganja kroz profit. Kako je već spomenuto da je za stvaranje profita nužno prepoznavanje, predviđanje i zadovoljenje potreba potrošača, tako se ukazala i potreba uvođenja marketinga u natjecateljski sport profitabilnog karaktera. Sportski marketing, u usporedbi $s$ različitim područjima gdje se marketing primjenjuje, počiva na istim elementima marketinškog miksa, ali je razlika u prirodi samih elemenata. Dok se kupac proizvoda nekog proizvodnog poduzeća oslanja jedino na uporabnu vrijednost samog proizvoda uz očekivanu razinu kvalitete, sportski proizvod sadrži više prostora za zadovoljenje korisnika. To se u prvom redu odnosi na niz osobina koje mogu korisnika sportskog proizvoda učiniti zadovoljnim (Beech, Chadwick, 2007).

Cilj ovog rada je na primjeru HNK-a Rijeka utvrditi je li postignut vrhunski rezultat u natjecateljskom sportu dovoljan za opstanak kluba. Pretpostavlja se da bez uloge sportskog marketinga nije moguće postići i poslovni rezultat kluba. Svrha je ukazati na presudnu ulogu marketinga u sportu u smislu stvaranja održivosti kluba.

\section{SPORTSKI MARKETING}

Marketinške aktivnosti vezane uz vrhunski sport već odavno potvrđuju da sport nije samo igra ili zabava, već zahtjevna djelatnost kojom dominiraju profitne organizacije. Među natjecateljskim sportovima značajno mjesto zauzima nogomet, o čemu će se više pažnje posvetiti u poglavlju koje slijedi. Suvremeni natjecateljski nogometni klub u velikoj mjeri ovisi o tržištu, zbog čega vodstva nogometnih klubova pri kreiranju poslovne politike trebaju uzimati u obzir marketing kao poslovnu koncepciju. Današnji nogomet u sebi sadrži elemente igre i zabave, a kroz sustav natjecanja profesionalnih klubova dobiva i značajnu poslovnu dimenziju (Hodak, Botunac, 2006:123-124).

Sportski marketing kao poslovna orijentacija počiva na koncepciji potražnje za sportskim proizvodima ili uslugama i zadovoljenja te potražnje uz uvažavanje koncepcije sportskog tržišta. Ukratko, sportski marketing povezuje proizvodnju sportskih proizvoda i usluga s njegovom potražnjom i konzumiranjem, obuhvaćajući pritom sva potpodručja sporta (Novak, 2006:223226).

\section{1 Marketing miks u sportu}

Da bi nogometni klub osigurao kvalitetan nastup na tržištu, nužno je poznavati i stalno pratiti tržišne ciljne skupine koje su relevantne za određivanje strategije marketing miksa. Glavne ciljne skupine nogometnog kluba su gledatelji i simpatizeri nogometa, mediji, gospodarski subjekti i uspješni nogometni klubovi u zemlji i inozemstvu (Hodak, Botunac, 2006:124).

Optimalnom kombinacijom elemenata marketing miksa sportski klub, sportaš, trener, organizator natjecanja ili vlasnik sportskog terena može utjecati na ostvarenje svojih marketinških ciljeva. Elementi marketing miksa u sportu su sportski proizvod ili usluge, cijena sportskih proizvoda ili usluga, mjesto (distribucija) sportskih proizvoda ili usluga te promocija sportskih proizvoda ili usluga (Draženović, Hižak, 2005:105). 


\subsubsection{Sportski proizvod}

Sportski proizvodi i usluge mogu se identificirati kao sportski programi (nematerijalne usluge) s primjenom u raznim sportskim granama te interdisciplinarni proizvodi sporta i komplementarnih djelatnosti (materijalne usluge). U nogometu, primjerice, sportski proizvod čini nogometna igra koja se realizira kroz sustav nogometnih utakmica te predstavlja nematerijalni oblik zadovoljavanja potreba određenih ciljnih skupina kroz potrošnju (Hodak, Botunac, 2006:125).

Sportski proizvod može se podijeliti u tri osnovne skupine (Novak, 2006:266-278): sportskoindustrijski proizvod, čisti sportski proizvod te integrirani sportski proizvod. Sportsko-industrijski proizvodi su proizvodi industrijskog podrijetla komplementarnih djelatnosti, a rezultat su interdisciplinarnog spoja sporta i drugih djelatnosti, poput korištenja sportske opreme. Čisti sportski proizvodi su raznovrsni programi s primjenom u sportu, koji se realiziraju na tržištu kratkotrajne neposredne potrošnje poput turnira, utakmica, liga. Ti su proizvodi isključivo rezultat sporta kao djelatnosti i nematerijalne su prirode. Kada je korištenje nekog proizvoda ili neke druge djelatnosti uvjetovano određenim sportskim proizvodom, tada se oni nazivaju integriranim sportskim proizvodom. Kao primjer može se spomenuti organizirano putovanje na Svjetsko prvenstvo u nogometu, gdje imamo spoj utakmice, usluge prijevoza, turističkog smještaja i usluge organizacije.

\subsubsection{Cijena sportskih proizvoda}

Cijena sportskih proizvoda ili usluga predstavlja novčani izraz vrijednosti sportskog proizvoda ili usluge (Pitts, Stotlar, 2007). U određivanju cijene proizvoda i usluga nogometnog kluba potrebno je uzeti u obzir interes i potražnju glavnih tržišnih ciljnih skupina, pozicioniranost nogometnog kluba u domaćim i međunarodnim natjecanjima, vrstu i značaj pojedine nogometne utakmice u odnosu s veličinom rashoda poslovanja (Hodak, Botunac, 2006:125). Drugim riječima, cijena je na neki način sredstvo pregovaranja s potrošačima, odnosno korisnicima usluga, ali i pokazatelj kvalitete poslovanja.

\subsubsection{Mjesto (distribucija) sportskih proizvoda}

Distribucija sportskih proizvoda predstavlja niz aktivnosti koje bi trebale osigurati kvalitetan dotok proizvoda od proizvođača do korisnika. U primjeru nogometa distribucija je uvelike određena utvrđenim sustavom natjecanja (prema gledateljima koji dolaze na stadion), dok kod drugog dijela gledatelja ovisi o broju i snazi TV kuća, značaju i razvoju kabelske televizije i drugim elementima (Hodak, Botunac, 2006:125-126).

Mjesto sportskog proizvoda odnosi se na to gdje i kako potrošači kupuju sportski proizvod. Sportsko se „mjesto“ odnosi na lokaciju koja predstavlja marketinški prostor gdje se okupljaju gledatelji, odnosno natjecatelji ili rekreativci. Mjesto je važan element marketing miksa s obzirom na to da može značajno utjecati na ostvarenje ukupnih marketinških ciljeva (Draženović, Hižak, 2005:112). 


\subsubsection{Promocija sportskih proizvoda}

Promocija kao element marketing miksa predstavlja zbroj različitih aktivnosti, nastojanja kojima organizacija ili kompanije potencijalne i stvarne potrošače upoznaju sa svojim proizvodima koji bi trebali postati i ostati poznati, a koje putem različitih medija unapređuju prodaju i osiguravaju konstantnu potražnju za njima. Takvo značenje promocije ima posebnu važnost za čisti sportski proizvod jer sportske priredbe imaju vrlo specifičnu značajku, a to je činjenica da je sportski spektakl uvijek nov, nikad viđen i neponovljiv, premijera bez reprize. Nadalje, sportsku promociju moguće je shvatiti kao funkciju informiranja ili djelovanja na ljude u vezi s proizvodima sportske kompanije, angažiranja društvene zajednice ili imidža (Draženović, Hižak, 2005:112). Značaj i važnost promocije može se shvatiti kada se uzme u obzir da je to oblik komunikacije s tržištem, odnosno s potencijalnim i aktualnim potrošačima.

Osnovne promotivne aktivnosti koje se najčešće koriste u sportskom marketingu su oglašavanje, osobna prodaja, odnosi s javnošću i publicitet.

Oglašavanje je sredstvo pomoću kojeg se tržište upoznaje s novim proizvodima i uslugama (Hodak, Botunac, 2006:126). Načini oglašavanja mogu biti poput oglasa, posjetnica ili omotnica, plakati ili ploče na stadionima, projekcijska, akustička i ostala tehnika. Ulaganje u ekonomsku propagandu čini se s ciljem utjecanja na potražnju sportskog proizvoda (Draženović, Hižak, 2005:113 -119).

Osobna prodaja podrazumijeva neposredni i interaktivni odnos između prodavača i potencijalnog kupca (Novak, 2006:309-310). Primjer osobne prodaje je prodaja sportske opreme u vrijeme treninga uz demonstraciju, prilikom rekreacije i sl.

Odnosi s javnošću dio su promotivnih aktivnosti kojima klub nastoji informirati javnost o važnim informacijama vezanim uz sam klub kao i stvaranje pozitivne slike o sebi. Efikasnost promocije kroz odnose s javnošću ovisi o odabiru ciljnih skupina, medija, poslovnih subjekata, strukovnih organizacija, međunarodnih organizacija $i \mathrm{dr}$. $U$ ovom segmentu promocije sportskih proizvoda posebnu važnost imaju predsjednik i glasnogovornik kluba, direktor kluba i sportski direktor, zatim bilteni, društvene mreže, internetske stranice, nogometni turniri i humanitarne utakmice te seminari u suradnji sa znanstvenim i stručnim institucijama (Hodak, Botunac, 2006:127).

Publicitet predstavlja neplaćeni oblik komuniciranja s javnošću pomoću raznih medija, gdje se kao predmet informiranja javlja aktivnost ili osobitost proizvoda ili usluge nekog poslovnog subjekta (Grbac, 2007). Sportski klub na taj način može objavljivati informacije o svojim aktivnostima, proizvodu, uslugama ili o svojim djelatnicima, kao i igračima.

\section{2 Svrha marketing miksa u sportu}

Marketing miks, kako je već navedeno, ima za svrhu optimalnom kombinacijom elemenata postići ciljeve poslovnih subjekata. U profesionalnom sportu ciljevi mogu biti ostvarenje prihoda za klub. Važan dio prihoda iz neproračunskih sredstava je sponzorstvo (http:// www.public.mzos.hr/fgs/, 10. 12. 2016.). Napori koje čine marketinški stručnjaci usmjereni 
su upravo u tom pravcu u smislu stvaranja preduvjeta za postizanje interesa kod sponzora, što je karakteristično za sportove poput nogometnih klubova. Osnove pojmove sponzorstva objasnit ćemo, stoga, u sljedećem potpoglavlju.

\subsection{Sponzorstvo - temeljne značajke}

Sponzorstvo je poslovni odnos u kojem privredni subjekt sudjeluje u organizaciji nekog događaja. To se sudjelovanje očituje kroz podmirivanje određenih troškova (u novcu, proizvodima ili uslugama) čime se stiče status sponzora u svrhu stvaranja vlastite promocije (Žugić, 2000:87).

Sponzorskim ugovorima potpisnici su jasno i nedvosmisleno vezani uz korištenje imena, lika ili robnog znaka (pravne osobe), njenog imidža, sportskih dostignuća i sportskih priredbi u svrhu promocije tvrtke, proizvoda, usluga ili ideja koje pruža kroz svoju djelatnost sponzor, a sve s određenim ciljem (Martins, 2004). Povezanost medija i sporta bitna su odrednica sponzorskog odnosa. Visina sponzorskih ugovora raste s medijskom eksponiranošću (Novak, 2006:325).

Sponzorstvo u nogometu čini onaj dio marketinških aktivnosti koje klubu omogućavaju stalne i stabilne izvore financiranja, a sponzorima mogućnost promocije svojih proizvoda i usluga radi što bolje prodaje. U visokorazvijenim europskim zemljama, uz prihode od televizijskih prava, sponzorstvo je najznačajniji izvor prihoda profesionalnih nogometnih klubova (Hodak, Botunac, 2006:127).

Vrhunski sportaši su javne osobe koje imaju snažan utjecaj na ljude, zbog čega imaju veliku marketinšku vrijednost. Zahvaljujući medijima, posebno televiziji, sport je postao vidljiv u cijelom svijetu. S marketinškog gledišta sportaši su tako i sami postali svojevrsne prepoznatljive sportske robne marke (Draženović, Hižak, 2005:105). Njihov imidž djeluje na okolinu privlačeći tako potencijalne sponzore.

\section{SPORTSKI MARKETING U HRVATSKOM NOGOMETNOM KLUBU RIJEKA}

U ovom poglavlju uz osnovne podatke o HNK-u Rijeka bit će govora o primjeni sportskog marketinga kroz kombinaciju elemenata marketing miksa u skladu s ciljevima kluba. Poslovanje HNK-a Rijeka kao profitne organizacije usmjereno je s jedne strane prema postizanju vrhunskih sportskih rezultata te s druge strane prema ostvarenju poslovnih ciljeva u smislu stvaranja prihoda. Da bi se to postiglo potrebno je uključiti i sponzorstvo kao značajan oblik financiranja te niz pratećih aktivnosti koje u velikoj mjeri potpomažu ostvarenje poslovnih rezultata.

\section{1 Počeci osnivanja i povijest HNK-a Rijeka}

Današnji HNK Rijeka vuče korijene iz davne 1926. godine, kada je 2. rujna osnovan nogometni klub Unione Sportiva Fiumana. Dvije godine kasnije igrao je u talijanskoj Serie A, zahvaljujući čemu su na Kantridi gostovali klubovi poput Intera (tada Ambrosiana) i Juventusa. Na otvaranju preuređene Kantride 1935. godine Fiumana je ugostila Romu, a u lipnju 1941. godine postala prvak talijanske Serie C. Dekretom jugoslavenske vlasti klub je ugašen u lipnju 1945. Godine, dok je godinu dana kasnije osnovan NK Kvarner kojem je pristupila većina igrača Fiumane, započevši igrati na stadionu Kantrida. NK Kvarner je 3. lipnja 1954. službeno promijenio ime u NK Rijeka. 
NK Rijeka ušao je prvu ligu u sezoni 1957./1958., gdje je opstao do sezone 1969./1970. te zatim prelazi u drugu ligu. Novi povratak među prvoligaše uslijedio je u sezoni 1973./1974.

Najveće uspjehe u svojoj povijesti NK Rijeka osvojio je u natjecanjima kupa, dva puta Kup Maršala Tita 1978. i 1979. godine, tri puta Kup Hrvatske 2005., 2006. i 2014. te jedan Superkup Hrvatske. NK Rijeka osvojio je Balkanski kup 1978. i igrao u završnicama državnih kupova 1987. i 1994. te tri puta bio najbolje plasirani hrvatski klub u prvoj jugoslavenskoj ligi. Ti su uspjesi, uz titule viceprvaka u sezonama 1998./1999., 2004./2005. i 2013./2014. postavili HNK Rijeka u sam vrh ljestvice hrvatskih klubova (Povijest, http://www.nk-rijeka.hr/hnk-rijeka/povijest/, 12. 8. 2016.).

\section{2 Promjene u vlasničkoj strukturi i organizacija kluba}

Grad Rijeka kao dugogodišnji vlasnik HNK-a Rijeka započeo je proces preoblikovanja kluba u sportsko dioničko društvo 2010. godine. Fondacija Social Sport u veljači 2012. godine potpisala je sporazum o ulaganju u klub, a mjesec dana kasnije Damir Mišković postao je predsjednik Uprave HNK-a Rijeka. Proces preoblikovanja dovršen je u rujnu 2013. godine kada je „Social Sport“ fondacija postala većinski vlasnik sa $70 \%$, dok ostatak dionica pripada Gradu Rijeci (http://www. nk-rijeka.hr/hnk-rijeka/vlasnicka-struktura/, 10. 12. 2016.)

„Social Sport" fondacija osnovana je 2010. godine u Amsterdamu. Glavni je cilj fondacije promocija i razvitak sportske kulture kod mladih diljem Afrike i Europe. Ključna osoba u fondaciji je Gabriele Volpi, ujedno i počasni predsjednik kluba. Njegovo poslovanje proteže se i na Afriku, točnije u Nigeriju, u kojoj također postoji nogometna Akademija Abuja. Selekcija Akademije često gostuje na Kvarnerskoj rivijeri prateći turnire i igrači koji se dokažu ostanu u Klubu, nakon čega odlaze na posudbu u druge klubove. Nakon promjene u vlasničkoj strukturi došlo je i do promjene u organizaciji HNK-a Rijeka.

Iz sheme 1 vidljiva je današnja organizacija kluba. Može se primijetiti kako su organizirani pojedini odjeli prema vrsti i aktivnosti djelovanja. Tako je, nama interesantan, marketing kao služba podijeljen na tri odjela. Odjel odnosa sjavnošću komunicira sa širokim masama putem web-sjedišta i društvenih mreža. Odjel organizacije događanja i promocije bavi se promotivnim aktivnostima. Odjel marketinga i komercijale obavlja kupoprodajne poslove kluba, kao i sve marketinške aktivnosti. 


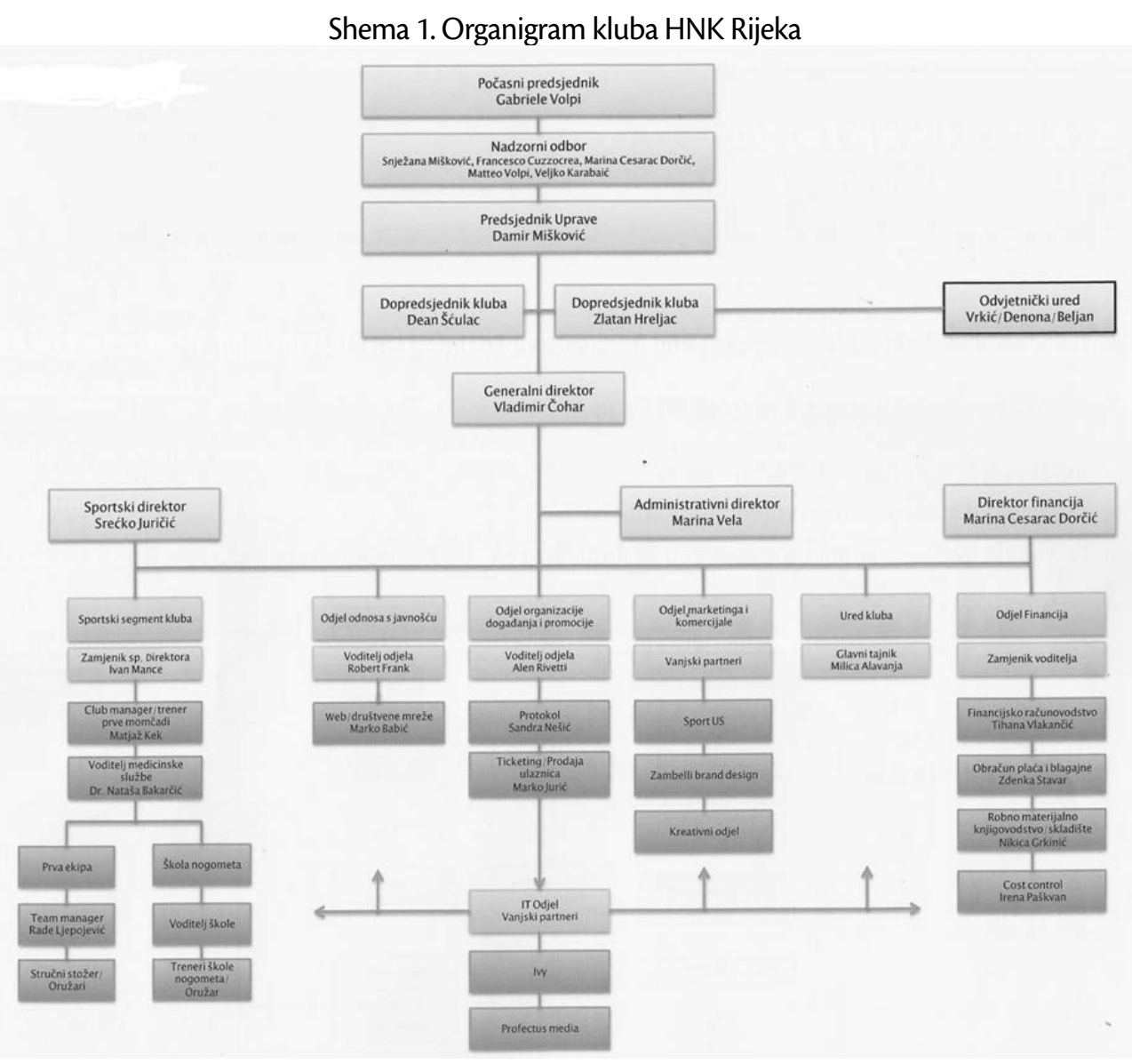

Izvor: Rezultati poslovanja i strateški plan, HNK Rijeka (2016:59)

\section{3 Promocija i kanali komunikacije HNK-a Rijeka}

U svrhu promocije i komunikacije sa svojom publikom HNK Rijeka koristi svoju internetsku stranicu, društvene mreže, HNK Rijeka TV i Stadion TV (video), prilog „Ajmo Rijeka“, newsletter i godišnjak HNK-a Rijeka (Marketing prezentacija, HNK Rijeka, 2016). Odjel organizacije događanja i promocije kao i Odjel odnosa s javnošću ovim se aktivnostima bavi svakodnevno ili periodično, ovisno o tipu ili vrsti događanja.

\subsubsection{Internetska stranica HNK-a Rijeka}

Internetska stranica Kluba prema podacima od 6. srpnja do 31. listopada imala je: 120.462 korisnika, 389.532 sesije, 1.336 .960 pregleda stranica, odnosno 956.701 jedinstvenih pregleda stranice (Marketing prezentacija, HNK Rijeka, 2016:12). 
Među najposjećenijim rubrikama bile su (Marketing prezentacija, HNK Rijeka, 2016:12):

- $\quad$ Vijesti (54.170 jedinstvenih pregleda, 85.974 pregleda)

- $\quad$ Raspored (22.362 jedinstvenih pregleda, 30.959 pregleda)

- S Škola nogometa HNK Rijeka (12.990 jedinstvenih pregleda, 20.489 pregleda).

\subsubsection{Društvene mreže i ostala sredstva komuniciranja}

HNK Rijeka redovito komunicira sa svojom publikom putem društvenih mreža. Analizirane su tri najpopularnije društvene mreže: Facebook, Twitter i Instagram. (www.businessinsider.com/ 10. 12. 2016.)

Grafikon 1. Broj fanova na Facebooku od 2012. do 2015.

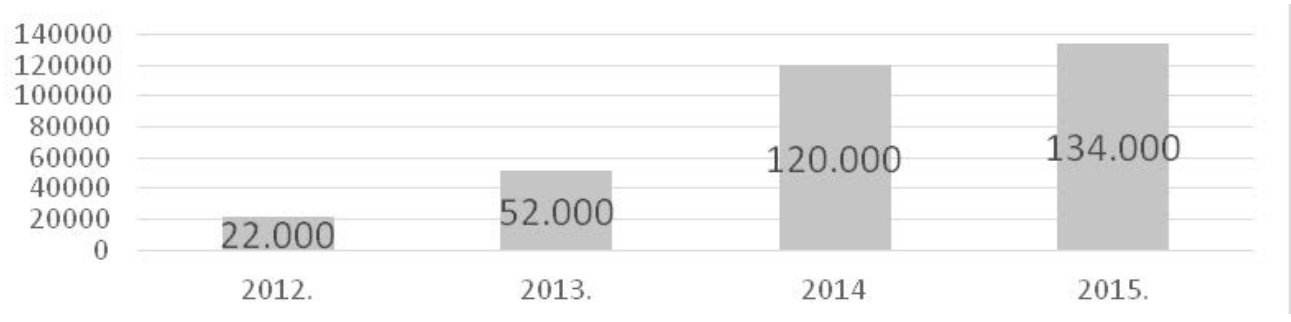

Izvor: obrada autora prema izvoru Marketing prezentacija, HNK Rijeka (2016:13)

Iz grafikona 1 vidi se porast broja fanova na Facebooku od 2012. do 2015. godine. Ipak se vidi da je porast broja fanova u periodu 2014./2015. znatno usporio, što se može pripisati zasićenju tržištem korisnika Facebooka, kao i korištenje alternativnih društvenih mreža, poput Twittera i Instagrama.

Slika 1. Broj obožavatelja na Facebooku prema spolu i državi

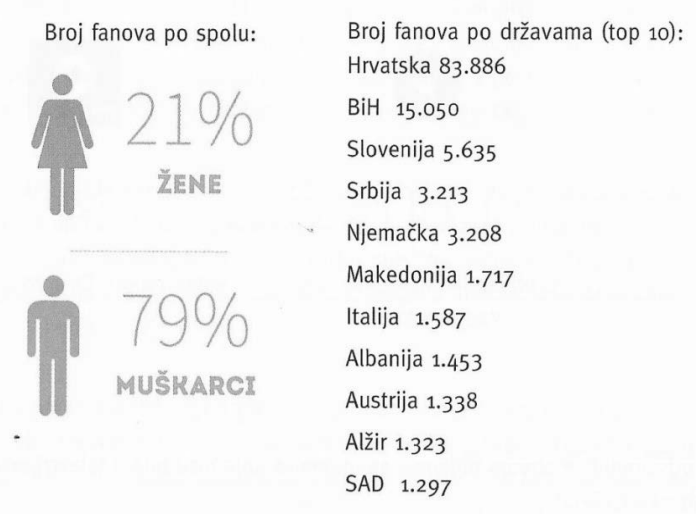

Izvor: Marketing prezentacija, HNK Rijeka (2016:13)

Struktura fanova na Facebooku prema spolu i državi vidi se iz slike 1. Većina njih (79\%) su muškarci, a 21 \% žene. Najveći broj fanova je iz Hrvatske, nakon čega slijede Bosna i Hercegovina, Slovenija, Srbija, Njemačka itd. 
Grafikon 2. Broj sljedbenika na Twitteru i Instagramu od 2012. do 2015.

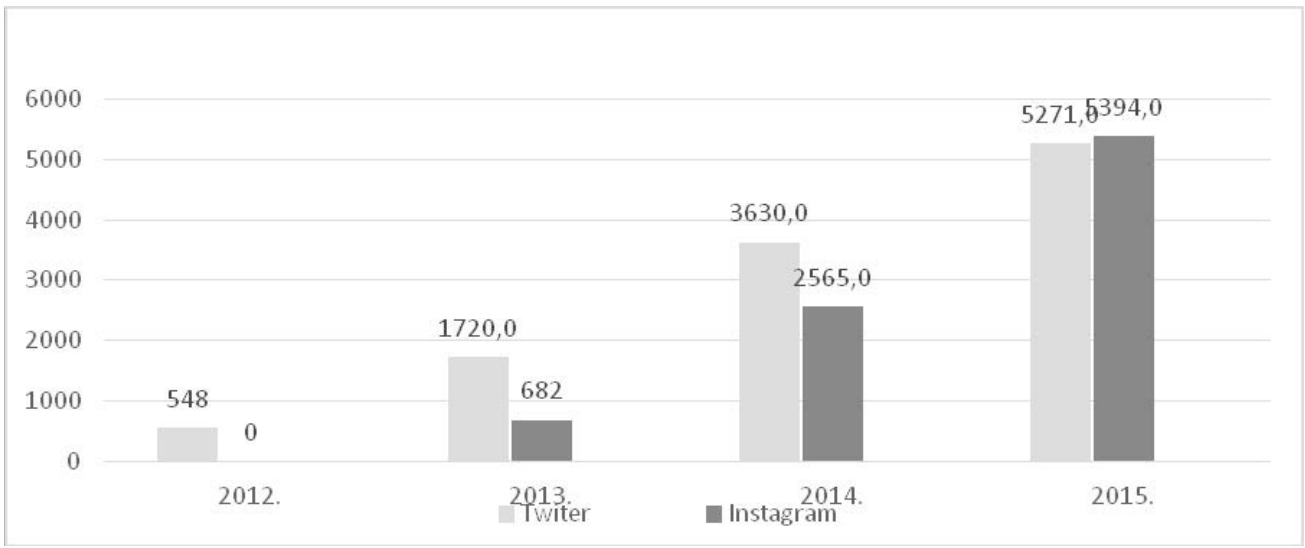

Izvor: obrada autora prema izvoru Marketing prezentacija, HNK Rijeka (2016:13)

lako Twitter i Instagram imaju manji broj članova nego Facebook, HNK Rijeka od 2012. godine bilježi stalni rast fanova i na ove dvije mreže, što je vidljivo na grafikonu 2. Porast fanova na Instagramu navodi nas na pitanje mijenja li se omjer navijača u korist ženskog spola. Naime, Instagram više koriste žene (68 \%), za razliku od muškaraca (32 \%) (www.businessinsider.com/ 10. 12. 2016.).

Klub neprestano ulaže i kreativno djeluje smišljajući različite projekte na društvenim mrežama; mediji su ga proglasili jednim od najaktivnijih klubova na društvenim mrežama 2015. godine ( www.netokracija.com/hnl-nogomet-drustvene-mreze,10.12. 2016.) Posebno se ističu infografike i kampanje Travanj na Kantridi i Nikad bliže. Isto su tako vrlo popularne fotografije „Behind the scene" koje su središte nogometnog kluba na profilu Instagrama.

HNK Rijeka ima vlastiti You tube kanal s 2.763 pretplatnika. Samo u 2014. godini na kanalu je bilo 447 videoreportaža, 588.764 pogleda i 1,669.537 pregledanih minuta (Marketing prezentacija, HNK Rijeka, 2016:14).

U rujnu 2015. godine na tržište se izašlo s novim sportskim proizvodom koji je napravljen u suradnji s Novim listom, čime se omogućila velika pojavnost i laka dostupnost. Radi se o mjesečniku „Ajmo Rijeka" koji promovira vrijednosti Kluba, piše o svim važnim temama za Klub, a poseban naglasak stavlja se i na školu nogometa (Marketing prezentacija, HNK Rijeka, 2016:12).

\section{4 Posjećenost, članovi i ulaznice}

Trenutno HNK Rijeka igra sezonu 2016./2017. u kojoj je odigrao 11 utakmica i nalazi se prvi na tablici Prve hrvatske nogometne lige. HNK Rijeka odigrao je 26 domaćih utakmica i prodao ukupno 78.271 ulaznica, ne računajući pakete ulaznica za Hrvatsku nogometnu ligu (u nastavku HNL). Broj korisnika paketa ulaznica za polusezonu povećao se na 2.616 za HNL te 6.186 za Europsku ligu. Ukupan broj gledatelja u polusezoni bio je 105.731 ili prosječno 6.608 gledatelja po utakmici. Broj registriranih članova kluba u sezoni iznosio je 3.746. Prema podacima za devet domaćih utakmica u prošloj sezoni, broj registriranih članova kluba bio je 3.413, a broj korisnika paketa 
ulaznica 2.926. Najposjećenija utakmica bila je protiv Aberdeena na kojoj je bilo 8.000 gledatelja. Najmanje posjećena utakmica bila je ona protiv Zagreba, na kojoj je bio 3.358 gledatelja (Marketing prezentacija, HNK Rijeka, 2016:6-7).

Klub omogućuje prodaju ulaznica na dva načina. Jedan je pretprodaja na blagajnama kod zapadnog ulaza u trening kamp HNK-a Rijeka, a drugi na sam dan odigravanja utakmice na zapadnim i istočnim blagajnama stadiona. Cijene ulaznica razlikuju se za članove kluba i ostale navijače.

Osim pojedinačnih ulaznica moguće je kupiti i komplete ulaznica. Cijena kompleta ovisi o tome radi li se o novom kupcu, prošlogodišnjem pretplatniku, kupcu koji nije član kluba i, naravno, sektoru za koji se kupuje komplet ulaznica, što se može vidjeti iz tablice 1 i 2.

Tablica 1. Cijene ulaznica

\section{MAXtv Prva liga - cijene ulaznica za članove}

\begin{tabular}{|c|c|c|c|c|}
\hline SEKTOR & REDOVNA CIJENA & $\begin{array}{l}\text { CIJENA NA DAN } \\
\text { UTAKMICE }\end{array}$ & DERBI CIJENA & $\begin{array}{l}\text { DERBI MA DAN } \\
\text { UTAKMICE }\end{array}$ \\
\hline $\mathbf{Z 6}$ & $220 \mathrm{kn}$ & $290 \mathrm{kn}$ & $250 \mathrm{kn}$ & $300 \mathrm{kn}$ \\
\hline 25 & $400 \mathrm{kn}$ & $490 \mathrm{kn}$ & $450 \mathrm{kn}$ & $550 \mathrm{kn}$ \\
\hline $24 / 27 / 28$ & $110 \mathrm{kn}$ & $140 \mathrm{kn}$ & $130 \mathrm{kn}$ & $150 \mathrm{kn}$ \\
\hline $21 / 22 / 29 / 210$ & $85 \mathrm{kn}$ & $110 \mathrm{kn}$ & $100 \mathrm{kn}$ & $120 \mathrm{kn}$ \\
\hline $11-15$ & $60 \mathrm{kn}$ & $80 \mathrm{kn}$ & $70 \mathrm{kn}$ & $90 \mathrm{kn}$ \\
\hline
\end{tabular}

MAXtv Prva liga - cijene ulaznica za ostale navijače

\begin{tabular}{|c|c|c|c|c|}
\hline SEKTOR & REDOVNA CIJENA & $\begin{array}{l}\text { CIJENA NA DAN } \\
\text { UTAKMICE }\end{array}$ & DERBI CIJENA & $\begin{array}{l}\text { DERBI MA DAN } \\
\text { UTAKMICE }\end{array}$ \\
\hline $\mathbf{Z 6}$ & $300 \mathrm{kn}$ & $350 \mathrm{kn}$ & $350 \mathrm{kn}$ & $400 \mathrm{kn}$ \\
\hline 25 & $500 \mathrm{kn}$ & $600 \mathrm{kn}$ & $600 \mathrm{kn}$ & $650 \mathrm{kn}$ \\
\hline$Z 4 / Z 7 / Z 8$ & $150 \mathrm{kn}$ & $200 \mathrm{kn}$ & $200 \mathrm{kn}$ & $250 \mathrm{kn}$ \\
\hline$Z 1 / Z 2 / Z 9 / 210$ & $130 \mathrm{kn}$ & $160 \mathrm{kn}$ & $160 \mathrm{kn}$ & $210 \mathrm{kn}$ \\
\hline $11-15$ & $85 \mathrm{kn}$ & $100 \mathrm{kn}$ & $100 \mathrm{kn}$ & $150 \mathrm{kn}$ \\
\hline
\end{tabular}

Izvor: http://www.nk-rijeka.hr/ulaznice/ (13. 8. 2016.) 
Tablica 2. Cijene kompleta ulaznica

\begin{tabular}{|c|c|c|c|c|c|c|}
\hline SEKTORI & $\begin{array}{l}\text { PROŠLOGODIŠNJI } \\
\text { PRETPLATNICI } \\
\text { TKO DOVEOE } \\
\text { PRIJATELJA' } \\
\text { PRIJATELJICU }\end{array}$ & $\begin{array}{l}\text { PROŠLO- } \\
\text { GODIŚNJI } \\
\text { PRETPLATNICI }\end{array}$ & $\begin{array}{l}\text { NOVI ČLANOVI } \\
\text { PRETPLATNICI } \\
\text { PRIJATELLJ/ } \\
\text { PRIJATELJICA }\end{array}$ & $\begin{array}{l}\text { SLOBODNA } \\
\text { PRODAJA } \\
\text { ĆLANOVI }\end{array}$ & $\begin{array}{l}\text { SLOBODNA } \\
\text { PRODAJA } \\
\text { NEČLANOVI }\end{array}$ & $\begin{array}{l}\text { STUDENTI } \\
\text { NEZAPOSLENI } \\
\text { UCCENICI } \\
\text { UMIROVLJENICI }\end{array}$ \\
\hline Z6 & $2425 \mathrm{kn}$ & $2500 \mathrm{kn}$ & $2625 \mathrm{kn}$ & $3600 \mathrm{kn}$ & $4320 \mathrm{kn}$ & \\
\hline $\mathbf{Z 5}$ & $5400 \mathrm{kn}$ & $5400 \mathrm{kn}$ & $5400 \mathrm{kn}$ & $5400 \mathrm{kn}$ & $7200 \mathrm{kn}$ & \\
\hline $\begin{array}{c}24 / 27 \\
28\end{array}$ & $1180 \mathrm{kn}$ & 1220 kn & $1280 \mathrm{kn}$ & 1998 kn & $2250 \mathrm{kn}$ & \\
\hline $\begin{array}{c}Z 1 / Z 2 \\
Z 9 / Z 10\end{array}$ & $1115 \mathrm{kn}$ & 1150 kn & $1210 \mathrm{kn}$ & $1440 \mathrm{kn}$ & $1710 \mathrm{kn}$ & \\
\hline $\begin{array}{l}11 / 12 \\
13 / 15\end{array}$ & $820 \mathrm{kn}$ & $850 \mathrm{kn}$ & $895 \mathrm{kn}$ & $1080 \mathrm{kn}$ & $1200 \mathrm{kn}$ & $450 \mathrm{kn}$ \\
\hline 14 & & $450 \mathrm{kn}$ & & $450 \mathrm{kn}$ & $450 \mathrm{kn}$ & \\
\hline
\end{tabular}

*Tribina 14 rezervirana je za članove Armade

Izvor: http://www.nk-rijeka.hr/kompleti-ulaznica/ (13. 8. 2016.)

Članom kluba postaje se ispunjavanjem pristupnice s potrebnim podacima i plaćanjem godišnje članarine koja iznosi 100 kn. Nakon učlanjenja, članovi dobivaju vlastite članske iskaznice. Također, kompleti ulaznica više nisu u papirnatom obliku već su modificirani obliku iskaznica.

Jedna od najvažnijih strategija kluba svakako je strategija samoodrživosti. Njome su postavljeni neki od najvećih ciljeva kluba, a jedan od njih je da se prihodima od ulaznica pokriju troškovi odigravanja utakmica s održavanjem sportskih terena i svim zavisnim troškovima.

Tablica 3. Prihodi od ulaznica i troškovi odigravanja

\begin{tabular}{|l|l|l|l|l|l|}
\hline & $\mathbf{2 0 1 2}$ & $\mathbf{2 0 1 3 .}$ & $\mathbf{2 0 1 4 .}$ & $\mathbf{2 0 1 5 .}$ & UKUPNO \\
\hline PRIHODI OD ULAZNICA & $\mathbf{2 , 0 8 7 . 9 3 5}$ & $5,827.242$ & $\mathbf{7 , 7 5 4 . 5 8 1}$ & $\mathbf{6 , 0 0 7 . 4 8 6}$ & $\mathbf{2 1 , 6 7 7 . 2 4 4}$ \\
\hline $\begin{array}{l}\text { TROŠK. ODIGRAVANJA } \\
\text { UTAKMICA SA } \\
\text { ZAVISNIM TROŠKOM }\end{array}$ & $\mathbf{- 3 , 1 5 5 . 5 7 6}$ & $\mathbf{- 8 , 9 9 5 . 9 6 3}$ & $\mathbf{- 9 , 1 7 6 . 4 6 2}$ & $\mathbf{- 8 , 2 8 3 . 7 7 3}$ & $-29,611.774$ \\
\hline $\begin{array}{l}\text { TROŠKOVI } \\
\begin{array}{l}\text { ODRŽAVANJA TERENA } \\
\text { ZA STADION KANTRIDA }\end{array}\end{array}$ & $\mathbf{- 3 , 6 1 7 . 1 4 6}$ & $\mathbf{- 4 , 8 0 3 . 1 4 6}$ & $\mathbf{- 4 , 3 5 3 . 0 8 6}$ & $-2,615.864$ & $\mathbf{- 1 5 , 3 8 9 . 2 4 2}$ \\
\hline TOTAL & $\mathbf{- 4 , 6 8 4 . 7 8 7}$ & $\mathbf{- 7 , 9 7 1 . 8 6 7}$ & $\mathbf{- 5 , 7 7 4 . 9 6 7}$ & $\mathbf{- 4 , 8 9 2 . 1 5 1}$ & $\mathbf{- 2 3 , 3 2 3 . 7 7 2}$ \\
\hline
\end{tabular}

Izvor: Rezultati poslovanja i strateški plan, HNK Rijeka (2016:14) 
U tablici 3 prikazani su prihodi od ulaznica i troškovi odigravanja utakmica te održavanja terena. Može se primijetiti da prihod od ulaznica još uvijek nije dovoljan da bi se niti približno ostvario spomenuti cilj. Klub se tako mora suočiti s određenim problemima i pitanjima. $U$ odnosu na utakmice koje su se igrale na Kantridi, cijene ulaznica na Rujevici su porasle. Primjera radi, cijena pretplate na Kantridi za tribinu D (zapadna tribina na kojoj su navijači Armade) iznosila je oko $250 \mathrm{kn}$, a danas je $850 \mathrm{kn}$. Pojedinačne cijene ulaznica na Kantridi kretale u se od 10 kn naviše, a na kampu za trening od $60 \mathrm{kn}$. Postavlja se pitanje kako bi se daljnje povećanje cijena odrazilo na potražnju.

\subsection{Sponzorstvo}

HNK Rijeka sklapa sponzorski ugovor samo s jednom markom iz kategorije, koja ima ekskluzivna prava povezivanja s markom, ekskluzivnu pojavnost na stadionu i u marketinškim materijalima te ekskluzivno pravo korištenja dogovorenih sponzorskih prava. U svim značajnijim kategorijama gdje postoji mogućnost komercijalne suradnje službeni sponzor dobiva ekskluzivna prava prodaje na stadionu i/li kubu te njegovim članovima. Sponzor dobiva i ekskluzivno pravo na korištenje znakovlja te slike trenera i igrača u svojim kampanjama. Isto tako može koristiti dva ili više igrača prvog tima za snimanje oglasa i slično. HNK Rijeka u prosjeku odigra 45 - 55 službenih utakmica, od kojih više od 20 na domaćem stadionu. Klub u potpunosti kontrolira sve marketinške aktivnosti i komercijalna prava za oglašavanje na LED elektronskim panoima (koji osiguravaju izravni prijenos; Arenasport TV - HNL i HRT - UEL), zatim oglašavanje na statičnim panoima (osiguravaju pojavnost u sažecima na nacionalnim TV stanicama; HRT, RTL, Nova TV i publici na stadionima), oglašavanje na velikom ekranu u trajanju od 30 sekundi tri puta na svakoj utakmici te oglašavanje preko razglasa gdje službeni spiker tijekom svake utakmice spomene sve sponzore. Sponzor dobiva i pravo na održavanje nagradnih igara na stadionu, dijeljenja promotivnih materijala i slično te jednu aktivnost poput players escort ili behind the scene tour. Sponzori kluba također imaju pravo na: premium VIP pozive i/li besplatne ulaznice za sve utakmice, aktivaciju kampanje na društvenim mrežama Kluba, stvaranje posebnih kampanji prema članovima HNK-a Rijeka i isticanje kampanje putem priloga „Ajmo Rijeka“, korištenje oglasnog prostora na službenoj stranici Kluba te pravo oblikovanja i predstavljanja posebne ponude za više od 50 partnera kluba. Logotipi svih sponzora istaknuti su na službenom zapisniku domaćih utakmica i ostalim tiskanim materijalima, a logotipi su također istaknuti na pozadini medija (engl. press backdropu) koji osigurava pojavnost $u$ medijskim izvještajima sa službenih konferencija za medije (Marketing prezentacija, HNK Rijeka, 2016:18-22). Popis službenih sponzora s popisom službenih dobavljača i medijskim partnerima nalazi se na službenim stranicama kluba.

Iznosi prihoda od sponzorstva i oglašavanja mogu se vidjeti u tablici 4. 
Tablica 4. Ukupni prihodi od sponzorstava i oglašavanja i ukupni troškovi škole nogometa

\begin{tabular}{|l|l|l|l|l|l|}
\hline & $\mathbf{2 0 1 2 .}$ & $\mathbf{2 0 1 3 .}$ & $\mathbf{2 0 1 4 .}$ & $\mathbf{2 0 1 5 .}$ & UKUPNO \\
\hline $\begin{array}{l}\text { PRIHODI OD } \\
\begin{array}{l}\text { SPONZORSTAVAI } \\
\text { OGLAŠAVANJA }\end{array}\end{array}$ & $3,112.820$ & $3,535.892$ & $3,984.560$ & $5,051.799$ & $15,685.071$ \\
\hline $\begin{array}{l}\text { TROŠKOVI ŠKOLE } \\
\text { NOGOMETA I RIJEKE 2 }\end{array}$ & $-4,165.564$ & $-5,010.532$ & $-10,009.092$ & $-10,023.642$ & $-29,208.829$ \\
\hline TOTAL & $\mathbf{- 1 , 0 5 2 . 7 4 4}$ & $\mathbf{- 1 , 4 7 4 . 6 4 0}$ & $\mathbf{6 , 0 2 4 . 5 3 2}$ & $\mathbf{- 4 , 9 7 1 . 8 4 3}$ & $\mathbf{- 1 3 , 5 2 3 . 7 5 8}$ \\
\hline
\end{tabular}

Izvor: Rezultati poslovanja i strateški plan, HNK Rijeka (2016:16)

Prema smjernicama strategije samoodrživosti HNK Rijeka planirano je pokriti troškove škole nogometa iz ukupnih prihoda od sponzorstava i oglašavanja. Kao što se vidi iz tablice, planirano nije ostvareno.

Prihodi od sponzorstva su važan izvor financiranja čije ostvarenje ovisi o kvaliteti marketinške politike. Uspjeh kluba prije svega ovisi o sposobnosti generiranja profita, a velik dio ostvaruje se marketinškim i prodajnim aktivnostima. Veći prihod pretpostavlja bolje sponzorske ugovore i jake partnere koje je mnogo lakše privući ako klub ima pozitivan imidž u javnost (Kase et al., 2006).

\section{ZAKLJUČAK}

Ciljevi sportskog kluba općenito su usmjereni prema postizanju vrhunskih sportskih rezultata prilikom natjecanja. $U$ tu svrhu ulažu se određena financijska sredstva i napori kako bi se postigli preduvjeti za ostvarenje ciljeva na tom planu. Ulaganja određenih financijskih sredstava obično čine veliku stavku u kategoriji troškova, što u odnosu s prihodima dovodi klubove u nezavidnu situaciju po pitanju opstanka ili prisutnosti na sportskoj sceni. Nedostatak prihoda jednako pogađa klubove s lošijim sportskim rezultatima, kao i klubove s boljim rezultatima. Razlog tome je što jedni vjerojatno manje ulažu u svoj razvoj, pa su im i troškovi u odnosu na prihode manji, dok drugi ulažu više, pa si im i troškovi veći. U svakom slučaju vrhunski rezultati u sportu pojedinog kluba nisu sami po sebi dovoljni za opstanak ili nekakav razvoj. Može se zaključiti da klub kao profitna organizacija osim spomenutih ciljeva treba imati i odgovarajuću poslovnu politiku koja im omogućava i ostvarenje poslovnih ciljeva uglavnom financijske prirode. Na taj način stvaraju određenu energiju potrebnu za funkcioniranje kluba u sportskom smislu. U sklopu poslovne politike poduzeća važnu ulogu ima sportski marketing s ciljem stvaranja i spajanja sportskih proizvoda sodređenim financijskim resursima na tržištu po osnovi zadovoljenja potreba i želja, kao i određenih interesa. Stvaranje pozitivne slike kluba u javnosti, izgradnja marke, bitni su preduvjeti za ostvarenje kvalitetnih sponzorstava koja mogu biti značajan izvor prihoda.

HNK Rijeka vrlo ozbiljno shvaća ulogu marketinga, na što upućuje činjenica da su u marketing kluba uključena tri odjela. Odjel odnosa s javnošću, Odjel organizacije događanja i promocije te Odjel marketinga i komercijale bave se pitanjima medija, marketinga i promocije. O važnosti marketinških aktivnosti usmjerenih prema svojim partnerima, sponzorima, navijačima i simpatizerima govore 


\section{R. Strahinja, M. Golob, T. Subašic: Sportski marketing u Hrvatskom nogometnom klubu Rijeka Zbornik Veleučilišta u Rijeci, Vol. 5 (2017), No. 1, pp. 71-86}

brojni kanali komunikacije kojima se klub koristi. Uz službenu internetsku stranicu, klub posebnu pozornost posvećuje društvenim mrežama na kojima je prošle godine bio jedan od najaktivnijih u HNL-u. Uz Facebook, HNK Rijeka ima profil na Twitteru i Instagramu. Na taj način spomenuti klub stvara simpatije i utječe na lojalnost i povećanje svojih obožavatelja, navijača i gledatelja. Uz to, pokrenuta je i HNK Rijeka TV koja na službenim stranicama donosi emisije o klubu, a koje se mogu pogledati i na vlastitom YouTube kanalu. Stadion TV producira se na službenom semaforu uoči utakmica. Klub uz mjesečnik „Ajmo Rijeka“ također izdaje i godišnjak.

Jedan od ciljeva HNK-a Rijeka, da se iz prihoda od cijene ulaznica pokriju troškovi odigravanja i održavanja terena, još nije ostvaren. Isto tako, cilj da se od sponzorstva i oglašavanja te ostalih komercijalnih prihoda s domaćeg tržišta pokriju svi troškovi škole nogometa i administracije je dio strategije samoodrživosti HNK-a Rijeka. O tome koliko je to zahtijevan cilj upućuje činjenica da usprkos konstantnim ulaganjima samoodrživost kluba još nije postignuta. No neodustajanje od navedenih ciljeva ipak ima rezultat podizanja kvalitete HNK-a Rijeka na višu razinu. Isto tako, poboljšanje ekonomske situacije u okruženju u kojem klub djeluje moglo bi stvoriti preduvjete za postizanje navedenih ciljeva.

Sve navedeno upućuje na to da je, i pored toga što HNK Rijeka ozbiljno shvaća ulogu marketinga i njegov značaj za klub, potrebno i dalje raditi na podizanju kvalitete marketinške službe, kako bi se klub doveo u bolju financijsku situaciju.

\section{LITERATURA}

Beech, J., Chadwick, S. (2007) The marketing od sport, Edinburgh, Essex, England, Pearson Education Limited

Draženović, D., Hižak M. (2005) Mogu ja i bolje: Sportsko komuniciranje i marketinške aktivnosti u sportu, Varaždin: TIVA- tiskara Varaždin

Grbac, B. (2007) Načela marketinga, Rijeka: Ekonomski fakultet Rijeka, Sveučilište u Rijeci

Hodak, Z., Botunac, R. (2006) Uvod u suvremeni nogomet, Zagreb: Reprocolor

Kase, K. et al. (2006) REAL MADRID - BARCELONA: BUSINESS STRATEGY V. SPORTS STRATEGY, 2000-2006, University of Navarra, Occasional Paper, 06/12-E,

Martins, R. B. (2004) „European Legal Football Match Heading for Extra Time“, The International Sports Law Journal, 4(3-4)

Novak, I. (2006, 2016) Sportski marketing i industrija sporta, Zagreb: Mailing

Pitts, B. G., Stolar, D. K. (2007) Fundamentals of sport Marketing, Fitness Information Tehnology, USA

Žugić, Z. (2000) Sociologija sporta, Zagreb: Fakultet za fizičku kulturu Sveučilišta u Zagrebu

Marketing prezentacija, HNK Rijeka, Rijeka, 2016.

Rezultati poslovanja i strateški plan, HNK Rijeka, Rijeka, svibanj 2016.

http: //www.businessinsider.com/(10. 12. 2016.)

http://www.jutarnji.hr/sport/sport-mix/forbesova-lista-brendova-federer-i-woods-vrijede-kao-tri-ronalda-imessija/916916/, (15. 8. 2016.)

http://www.totalweb-seo.com/hr/blog/2013/svibanj/drustvene-mreze-i-marketing, (14. 8. 2016.)

http:// www.netokracija.com/hnl-nogomet-drustvene-mreze, (10. 12. 2016.) 
http://www.nk-rijeka.hr/hnk-rijeka/kamp/, (12. 8. 2016.)

http://www.nk-rijeka.hr/hnk-rijeka/vlasnicka-struktura/, (10. 12. 2016.)

http://www.virtualna-tvornica.com/marketing-na-drustvenim-mrezama/, (14. 8. 2016.).

http://www.nk-rijeka.hr/hnk-rijeka/povijest/, (12. 8. 2016.)

http://www.nk-rijeka.hr/ulaznice/, (13. 8. 2016.)

http://www public.mzos.hr/fgs/, (10.12. 2016.)

Zakon o medijima, čl. 2, NN 59/04, 84/11, 81/13, http://www.zakon.hr/z/38/Zakon-o-medijima, (14. 8. 2016.)

Zakon o zaštiti potrošača, NN 41/14, 110/15, http://www.zakon.hr/z/193/Zakon-o-za\%C5\%A1titipotro\%C5\%A1a\%C4\%8Da, (14.8. 2016.) 


\title{
SPORTS MARKETING IN CROATIAN FOOTBALL CLUB RIJEKA ${ }^{4}$
}

\begin{abstract}
Certain sports have become highly ranked on the scale of interest in today's society due to popularization of competitive sports. Football occupies a very special place among modern popular competitive sports. One of the many reasons of such popularity is certainly it's financial nature. It is widely known that huge funds are invested in football clubs and their respective players that can reach notably high prices on the player markets. Marketing plays an important role in the football world, without a doubt. Although Sports marketing is essentialy no different than marketing of any other business on the market, there are some differences that can be observed in individual elements of the marketing mix. With before mentioned in mind, sport products have a very large range of possibilities to meet the needs of consumers themselves. This paper examines CFC Rijeka whose impressive results in terms of sport achievements, and without additional investments in marketing, are not sufficient enough for obtaining positive business results. Satisfying business results can only be expected by investing financial resources and by implementing a specificaly selected marketing strategy. There are numerous forms of financing the FC Rijeka right now, but the longterm goal is to be a self-financing football club on a higher level than now. Because of this objective, marketing activities of the club are focused on a form of promotion that result in increased financial resources induced through fandom, fans and the public in general.
\end{abstract}

Key words: sports marketing, sport product, promotion, CFC Rijeka

MSc., Lecturer, Polytechnic of Rijeka, Vukovarska 58, 51000 Rijeka, Croatia. E-mail: robert.strahinja@veleri.hr Univ. spec. oec., assistent, Polytechnic of Rijeka, Vukovarska 58, 51000 Rijeka, Croatia. E-mail: mgolob1@veleri.hr Student, Polytechnic of Rijeka, Vukovarska 58, 51000 Rijeka, Croatia. E-mail: tsubasic@veleri.hr Received: 15 January 2017; Accepted: 15 March 2017 